\title{
An Applied Research on the Stratified Teaching Model in Basketball Teaching
}

\author{
Zhangzhu Li \\ School of Physical Education, Neijiang Normal University, Neijiang City, \\ Sichuan Province, 641199, China
}

\begin{abstract}
In the practice of basketball teaching for many years, the author finds that it is difficult for poor students to accept the "one size fits all" teaching model and excellent students can not improve themselves, which causes that basketball teaching does not meet the actual physical needs of students. Stratified teaching model is a new teaching method based on differences of students' physical fitness, specific technical level, curricula-variable motivation and the understanding of the basketball. Based on the author's teaching practice, this paper firstly analyzed the applicability of the stratified teaching model in basketball teaching and then proposed the implementation steps of the stratified teaching model.

Keywords: Stratified teaching; Basketball teaching; Applicability;
Implementation steps
\end{abstract}

\section{Introduction}

The stratified teaching refers to dividing students into different groups according to the differences in their learning ability in the teaching. Teachers set different teaching objectives and teaching tasks for students based on the actual situation of these groups, and then use different teaching methods, so as to improve students' basketball skills in basketball study ultimately[1]. Innovative measures of basketball teaching require teachers to scientifically grasp the relationship between collective teaching, group teaching and personal teaching to truly realize the teaching objective of teaching students in accordance of their aptitude. The basketball stratified teaching just meets this requirement. 


\section{The Applicability of the Stratified Teaching Model in Basketball Teaching}

\subsection{The stratified teaching model is conducive to achieving students' stage objectives}

Because of the differences in students' congenital physical qualifications and their mastery and knowledge level of basketball technology, if teachers take the unified teaching for all students to achieve the same teaching goal and use the same teaching method, it will cause that some students want to learn more in the limited time, while some students cannot master skills in the class. Therefore, in order to establish a good learning confidence for all students, teachers should set different stage objectives for different students. For example, moderate anxiety helps students improve their academic performance in the learning, but excessive anxiety is bound to affect students' physical and mental health. The construction of the stratified teaching model is to create a relaxing and pleasant learning atmosphere for students, so that students can learn and live in an environment with moderate anxiety and the teaching will fit each student's zone of proximal development. Then, students will gain self-confidence in learning[2].

\subsection{The stratified teaching model is in line with the objective law of the basketball development}

Stratified teaching model emphasizes the individual differences and individualized teaching which provides a good foundation and prerequisite for the formation and development of individual sports skills. Moreover, students' cognition can develop from the shallower to the deeper. In other words, students can grasp the sports skills first and ultimately consolidate and improve these skills. This teaching model is in line with the objective law of the basketball development.

\subsection{The stratified teaching model accords with requirements of the quality education}

The important implication of basketball teaching is the entirety, which means the basketball is for all students, so that each student can master basic knowledge, skills and techniques of the basketball[3]. The stratified teaching is to design different teaching objectives based on the requirements of the outline and teaching materials in the teaching, which focuses on students' different ability. Then, teachers make learning requirements for students with different levels based on teaching objectives, give different guidance and make tests with various level, so that students with all levels can choose different learning speed, the practice difficulty, and knowledge and information with different levels that conforms to their own situation. Therefore, each student can learn something and gain knowledge, which fully embodies the entirety of quality education. 


\subsection{The stratified teaching conforms to the acceptable principle}

"The acceptable principle requires that teaching arrangements should be tailored to students' actual learning potential, so that they do not feel stressed intellectually, physically, or mentally," said Babansky, a Soviet educator. The difference in students' ability is mainly reflected in the learning speed and not necessarily reflected in the final reachable level of learning and teaching objectives.

\section{The Implementation Steps of the Stratified Teaching Model in Basketball Teaching}

\subsection{Teachers need to update the concept of basketball education}

Teachers should update the teaching concept of basketball education. In the teaching practice, teachers should take students as the core and give full play to the subject role. Moreover, teachers need to divide the teaching objects according to the initial technical level, so that students can have a better understanding of their situation. This will help students train the correct sports values and attitudes. After the division and a period of observation, teachers should make new orientations and readjustment according to students' existing technical level and changes. With the changes of students' learning interest, sports performance and athletic ability, teachers can constantly arouse students' motivation to learn, change their attitude, improve their learning enthusiasm and harmonize the emotion between teachers and students[4]. If the stratification has not changed for a long term, it will strike students' enthusiasm and learning interest, so that students can not experience the thrill of movement, and the joy and excitement brought by the success and progress, which strangles students' desire for knowledge and the non-ideal teaching effect.

\subsection{The basketball teaching objectives should be hierarchical}

The new teaching concept is for all students, so that each student can gain knowledge and have a successful experience. Teachers should create conditions for excellent students to make improvements; they should not discriminate students with weak acceptance and should enable them to build confidence and gradually improve their ability. Only the development of each student's education is a successful education. Physical education teachers should design hierarchical teaching objectives respectively based on stratified teaching theory, so that students can surpass themselves through their own efforts. The class with higher learning level should continuously improve the sports technology, establish sports skills goals, enhance the physical fitness, make the development goals clear and improve their analysis and problem-solving ability to achieve higher teaching objectives. For the class with middle learning level, teachers should make them grasp the basketball knowledge and sports skills. Moreover, they should think 
independently, cultivate their problem-solving and analysis ability and establish the sports goals[5]. Besides, teachers should complete the basic teaching objectives and encourage students to participate in teaching activities with higher level objectives actively. For the class with lower learning level, teachers should mobilize students' enthusiasm for learning, recognize their flash point, so that students can build self-confidence, overcome the difficulties and have the confidence to face challenge. Furthermore, teachers should create conditions and give students exercise opportunities to make them remain an active state. Teachers should pay attention to cultivating their self-learning ability, so that they can grasp the most basic theoretical knowledge in teaching materials and master the necessary sports skills to participate in sports. They should focus on the completion of physical and mental health goals, and the general teaching objectives[6].

The experimental study in psychology shows that for the same learning effect, teaching with definite goals can save a lot of time than the teaching with obscure objects. After the introduction of the new lesson, students with all levels should make the specific objectives clear and the course should be carried out closely around teaching objectives. This can effectively reduce and control interference factors and ineffective labor of the teaching. When teachers design the goals of hierarchical teaching, the goal should be targeted for students with different levels.

\subsection{Teachers' lesson preparation should be hierarchical}

The individual differences of students' cognition structure in their own development are mainly reflected in differences in basic knowledge and the mastery of basic skills, differences in learning methods, habits and abilities, and differences in adaptation to the classroom teaching environment and teachers' teaching methods. These differences lead to that students are divided into three levels, namely, excellent students, general students and students with learning difficulties. The distribution of students' receptivity is a normal distribution, which means that the first and the last groups have fewer students while the middle group has more students. Students divided according to the interest have different levels, so the progress and teaching content should not be unified. Therefore, teachers should design the corresponding teaching methods according to the actual situation and establish the appropriate teaching program based on the syllabus and teaching materials. Teachers should pay attention to systematicness and hierarchy in all aspects of the teaching[7]. The actual teaching should not only meet requirements of students' individual differences and teachers should take into account of all students to achieve individualized teaching, so that it can effective play the main role of the students and the leading role of teachers to improve the teaching quality of physical education.

\subsection{The layered target test in the assessment}

In basketball teaching, the single assessment is a common problem. The drawbacks of this assessment is that students in good health do not need to 
practice and they can gain better results; poor students continue to practice and the results are still bad, thus restricting students' learning enthusiasm. Quality education is a kind of education with the comprehensive development and sports is for all students. Sports assessment should be diverse and three-dimensional. For a few top athletes, teachers can not pay too much attention to them nor suppress their sports expertise and personality development too much. For a small number of poor students, teachers should take notice of their progress and the assessment for their academic performance should focus on their evaluation of the effort level. In the development of assessment standards, teachers should not only have unified requirements, but also have different evaluation criteria to establish an evaluation system which has incentive function for all students with different levels. In physical education, the assessment for students should be based on the characteristics of sports disciplines and take a scientific approach. The education should not only exercise the students' body, but also develop students' thinking skills to improve their intellectual level and teach students how to behave. Therefore, the assessment should be carried out based on individual differences. In this way, teachers can better grasp the integrity of the teaching process, otherwise it will result in the dis-junction between teaching and test, and dampening students' enthusiasm.

\section{Conclusion}

The stratified teaching model in basketball teaching respects students' interests and fully embodies the guiding ideology of student-oriented education, which realizes the teaching principle of physical education to all students and profoundly recognizes the objectivity of individual differences. This method teaches student in a targeted and different way and teach students in accordance of their aptitude, so as to meet students' learning needs to the extended degree. Therefore, each student can have the optimal development, so as to help students establish a successful belief and self-confidence. Consequently, the implementation of stratified teaching in basketball teaching has important practical significance.

\section{References}

[1] Kan Jie. A Study on the Construction of Basketball Stratified Teaching and Training Model in Colleges. Sports, (11), pp.102-103, 2016.

[2] Liu Gang. A Study on the Application of the Stratified Teaching in Basketball Teaching in Colleges. Contemporary Sports Technology, (16), pp.108-109, 2015.

[3] Wen Xizhuang. A Research of the Practice of Stratified Teaching in the Basketball Selective Courses in Colleges. Journal of Liaodong University (Natural Sciences Edition), (04), pp.291-293, 2013.

[4] Jiang Qin. A Study on the Application of the Target Stratified Teaching in 
Basketball Teaching in Junior High Schools. Contemporary Sports Technology, (31), pp.65-67, 2013.

[5] Jiang Yan. A Study on the Application of the Stratified Teaching in Basketball Teaching in Colleges. Sports World (On the Trimonthly Publication), (05), pp.101-102, 2013.

[6] Xie Bing. A Study on the Application of the Stratified Teaching in Basketball Teaching in Colleges. Sports, (02), pp.84-85, 2011.

[7] Xie Yeshou, Chen Jun. A Research of the Practice Exploration of Stratified Teaching in the Basketball Selective Courses in Colleges. Journal of Capital Institute of Physical Education, (02), pp.232-234, 2009. 